\title{
Kombinasi Diskusi Kelompok Kecil dan Pemodelan sebagai Metode Alternatif untuk Menurunkan Kecemasan Primigravida Menghadapi Persalinan
}

\section{Combination of Buzz Group and Modelling Method to Reduce Primigravida Anxiety}

\author{
Viqy Lestaluhu1, IW Agung Indrawan', Sri Andarini \\ ${ }^{1}$ Program Studi Magister Kebidanan Fakultas Kedokteran Universitas Brawijaya Malang \\ ${ }^{2}$ Departemen Obstetri \& Ginekologi Fakultas Kedokteran Universitas Brawijaya Malang \\ ${ }^{3}$ Departemen Ilmu Kesehatan Masyarakat Fakultas Kedokteran Universitas Brawijaya Malang
}

\begin{abstract}
ABSTRAK
Kehamilan pertama bagi seorang ibu merupakan periode krisis dalam kehidupannya. Kecemasan dapat muncul karena masa panjang menanti kelahiran dan ketidakpercayaan diri lbu merawat bayinya. Oleh karena itu, primigravida membutuhkan informasi yang memadai tentang persiapan persalinan. Kombinasi diskusi kelompok kecil dan pemodelan merupakan metode pembelajaran yang bermanfaat dalam meningkatkan derajat kesehatan ibu, salah satunya dengan menurunkan kecemasan dalam menghadapi persalinan. Penelitian ini bertujuan membuktikan pengaruh penerapan kombinasi metode diskusi kelompok kecil dan pemodelan terhadap kecemasan primigravida dalam menghadapi persalinan. Desain penelitian adalah true eksperimen dengan rancangan randomized subject, pretest-posttest control group design. Penelitian dilakukan di Puskesmas Poka Rumah Tiga Kota Ambon. Sampel dalam penelitian ini sebanyak 24 responden yang dibagi 2 kelompok yaitu kelompok intervensi dan kontrol. Pengukuran kecemasan primigravida menghadapi persalinan menggunakan Hamilton Anxiety Rating Scale (HARS). Data dianalisis dengan uji paired t-test dan independent $t$-test dengan $\alpha=0,05$. Hasil penelitian menunjukkan terdapat perbedaan yang signifikan kecemasan primigravida menghadapi persalinan sebelum dan setelah penerapan kombinasi metode diskusi kelompok kecil dan pemodelan serta antara kelompok intervensi dan kelompok kontrol $(p=0,000)$. Dapat disimpulkan bahwa penerapan kombinasi metode diskusi kelompok kecil dan pemodelan dapat menurunkan kecemasan primigravida dalam menghadapi persalinan.
\end{abstract}

Kata Kunci: Diskusi kelompok kecil, kecemasan, pemodelan, persalinan, primigravida

\section{ABSTRACT}

For mother, first pregnancy is a critical period in her life. Anxiety may come up due to a long period to wait for the baby birth and self-distrust feeling insecure of the mother to take care the baby. Therefore, primigravida needs sufficient information on delivery preparation. Combination of buzz group and modelling methods is a useful instructional method to improve mothers' health level, one of them is by reducing their anxiety toward delivery. This study aimed at proving the effect of applying combination of buzz group and modelling methods on primigravida anxiety in facing delivery. The research design was true experiment with randomized subject design with pre-test post-test control group design. The study was conducted at Poka Rumah Tiga Public Health Center in Ambon. The samples in this study were 24 respondents divided into 2 groups, namely intervention and control group. Measurement of primigravida anxiety facing childbirth was useing Hamilton Anxiety Rating Scale (HARS). Data were analyzed using paired t-test and independent $t$-test with $\alpha=0.05$. The results show that there are significant differences in primigravida anxiety in facing delvery before and after the application of a combination of small group discussion and modeling methods and between the intervention group and the control group ( $p=0.000)$. It can be concluded that the application of a combination of small group discussion and modeling methods can reduce primigravida anxiety in the facing the delivery.

Keywords: Anxiety, buzz group, delivery, modelling, primigravida

Korespondensi: Viay Lestaluhu. Program Studi Magister Kebidanan Fakultas Kedokteran Universitas Brawijaya Malang. Jl. Veteran Malang 65145 Email: viqylestaluhu@gmail.com

DOI: http://dx.doi.org/10.21776/ub.jkb.2018.030.02.13 


\section{PENDAHULUAN}

Kehamilan merupakan salah satu periode terpenting dalam kehidupan seorang wanita karena membawa banyak perubahan. Perubahan yang terjadi dapat berupa perubahan fisik maupun psikologis. Seiring dengan bertambahnya usia kehamilan akan semakin meningkat kecemasan Ibu hamil terutama pada primigravida $(1,2)$. Kecemasan ibu hamil dapat berhubungan dengan persalinan lama, persalinan prematur, berat lahir rendah, dan persalinan dengan sectio caesarea yang tidak direncanakan (2). Kecemasan selama kehamilan bervariasi di setiap wanita. Penelitian di Spanyol mengungkapkan bahwa 174 ibu hamil trimester ketiga memilki tingkat kecemasan lebih tinggi dibandingkan tingkat rata-rata populasi umum (3). Angka kecemasan di Indonesia memiliki angka yang bervariasi di setiap wilayah. Beberapa penelitian membuktikan bahwa prevalensi kecemasan primdigravida lebih tinggi dibandingkan dengan multigravida $(4,5)$. Menurut penelitian yang dilakukan oleh Kalayil et al, tahun 2015 didapatkan 93\% ibu hamil dengan kecemasan menghadapi persalinan pada trimester ketiga (2).

Permasalahan tersebut memerlukan perhatian bagi tenaga kesehatan khususnya bidan dalam meningkatkan pelayanan kebidanan yang berkualitas. Pelayanan yang diberikan dapat berupa pelayanan Ante Natal Care (ANC). Dengan mendapatkan informasi yang tepat dari pelayanan ANC tentang persiapan menghadapi persalinan, maka akan mempengaruhi tingkat kecemasan ibu dalam menghadapi persalinan terutama pada primigravida $(6,7)$. Selain metode yang diterapkan pada pelaksanaan kelas Ibu hamil, masih banyak metode pembelajaran lain yang dapat meningkatkan pengetahuan dan keterampilan Ibu hamil sehingga dapat mempengaruhi kecemasan Ibu tersebut. Salah satu metode pendidikan kesehatan yang direkomendasikan oleh UNICEF adalah diskusi kelompok kecil. Diskusi kelompok kecil merupakan metode yang cepat dan efisien dalam mengumpulkan umpan balik pada topik tertentu dan dapat memecahkan suatu masalah bersama-sama (8). Menurut Ernest W. Brewer, agar mendapat hasil yang lebih efisien, metode diskusi kelompok kecil sering digunakan dalam kombinasi dengan metode pendidikan kesehatan lainnya (9). Salah satu metode dalam pendidikan kesehatan yang dapat meningkatkan kemampuan dan keterampilan adalah pemodelan (10).

Kelebihan dari kombinasi metode diskusi kelompok kecil dan pemodelan yaitu membantu peserta untuk dapat menyampaikan pendapat atau gagasan di dalam kelompok, menghindari peserta yang terlalu banyak bicara dan tidak memperhatikan materi yang dipresentasikan $(11,12)$. Berdasarkan hasil studi pendahuluan yang dilakukan di Puskesmas Poka Rumah Tiga Kota Ambon, peneliti menemukan sebagian besar primigravida mengalami kecemasan dalam menghadapi persalinan. Tujuan dari penelitian ini adalah untuk membuktikan pengaruh penerapan kombinasi metode diskusi kelompok kecil dan pemodelan terhadap kecemasan primigravida dalam menghadapi persalinan.

\section{METODE}

Desain penelitian yang digunakan adalah true experiment dengan rancangan randomized subject, pretest-posttest control group design. Penelitian ini dilakukan di Puskesmas Poka Rumah Tiga Kota Ambon pada bulan November sampai dengan Desember 2017. Sampel diambil berdasarkan kriteria inklusi yang meliputi: (1) bersedia menjadi responden, usia 20-35 tahun; (2) kehamilan pertama, usia kehamilan $\geq 28$ minggu; (3) berpendidikan minimal SMA; (4) ibu hamil dengan risiko rendah; (5) tidak sedang mengkonsumsi obat cemas; (6) memiliki skor kecemasan dengan nilai lebih dari 6. Serta kriteria eksklusi yaitu memiliki riwayat gangguan jiwa. Kriteria dropout meliputi: (1) responden yang tidak hadir pada saat penelitian berlangsung; (2) responden tidak menyelesaikan sesi diskusi kelompok kecil dan pemodelan. Besar sampel pada penelitian ini menggunakan sampel minimal sesuai penelitian eksperimen yaitu masingmasing kelompok sebanyak 10 responden. Untuk mengantisipasi adanya drop out dalam penelitian, maka peneliti menambahkan sejumlah subjek agar besar sampel tetap terpenuhi, menggunakan perhitungan sebagai berikut: $n^{\prime}=n /(1-f) \quad(13,14)$. Total keseluruhan sampel menjadi 24 responden dengan jumlah masing-masing kelompok sebanyak 12 responden.

Penarikan sampel dilakukan dengan menggunakan teknik consecutive sampling (14). Setelah jumlah sampel terpenuhi sampel dibagi secara random/acak menggunakan undian dan dibagi menjadi dua kelompok yaitu kelompok intervensi sebanyak 12 responden yang diberikan penerapan kombinasi metode diskusi kelompok kecil dan pemodelan dan kelompok kontrol sebanyak 12 responden yang hanya diberikan modul persiapan persalinan dan keterampilan merawat bayi. Instrumen yang digunakan dalam pengukuran kecemasan primigravida dalam menghadapi persalinan adalah kuesioner Hamilton Anxiety Rating Scale (HARS) $(4,15)$. Penerapan kombinasi metode diskusi kelompok kecil dan pemodelan diberikan sesuai dengan standar operasional prosedur (SOP) pada kedua metode tersebut dan satuan acara pengajaran (SAP).

Penerapan kombinasi metode diskusi kelompok kecil dan pemodelan diberikan pada 1 kali pertemuan dengan waktu \pm 120 menit. Alat bantu yang digunakan meliputi flipchart, leaflet, alat tulis dan alat peraga beserta perlengkapannya. Pengukuran kecemasan primigravida dalam menghadapi persalinan dilakukan sebanyak 2 kali (pre-test dan posttest). Untuk menghindari bias dalam penelitian ini, pengukuran kecemasan primigravida dalam menghadapi persalinan dengan bantuan enumerator. Sebelum dilakukan pengukuran telah diadakan training dan persamaan persepsi terlebih dahulu dengan enumerator.

Data dianalisis dan diinterpretasikan dengan menguji hipotesis menggunakan SPSS 23.0. Analisis data bivariat menggunakan uji paired t-test dan independet t-test. Uji paired t-test digunakan untuk menganalisis perbedaan kecemasan primigravida dalam menghadapi persalinan sebelum dan setelah diberikannya intervensi. Sedangkan Uji independet t-test digunakan untuk menganalisis perbedaan nilai delta kecemasan primigravida dalam menghadapi persalinan pada kelompok intervensi dan kelompok kontrol.

\section{HASIL}

\section{Karakteristik Responden}

Pada penelitian ini, karakteristik responden berdasarkan usia, pendidikan dan usia kehamilan dibatasi sesuai kriteria inklusi. Usia responden yaitu 20-35 tahun dan berpendidikan minimal SMA dengan usia kehamilan $\geq 28$ minggu. Gambaran karakteristik perkerjaan, menunjukkan sebagian besar adalah Ibu Rumah Tangga baik itu pada kelompok intervensi sebanyak 10 orang $(83,3 \%)$ dan kelompok kontrol sebanyak 9 orang $(75,0 \%$ ) (Tabel 1). 
Tabel 1. Karakteristik responden berdasarkan pekerjaan

\begin{tabular}{lccccc}
\hline Variabel Kategori & \multicolumn{2}{c}{ Kelompok Intervensi } & \multicolumn{2}{c}{ Kelompok Kontrol } \\
\cline { 3 - 6 } & & $\begin{array}{c}\text { Jumlah } \\
(\mathbf{n})\end{array}$ & $\begin{array}{c}\text { Persentase } \\
(\%)\end{array}$ & $\begin{array}{c}\text { Jumlah } \\
\text { (n) }\end{array}$ & $\begin{array}{c}\text { Persentase } \\
(\%)\end{array}$ \\
\hline Pekerjaan & IRT & 10 & 83,3 & 9 & 75,0 \\
& PNS & 1 & 8,3 & 1 & 8,3 \\
& Swasta & 1 & 8,3 & 2 & 16,7 \\
\hline
\end{tabular}

Keterangan: IRT: Ibu Rumah Tangga; PNS: Pegawai Negeri Sipil

\section{Kecemasan Primigravida dalam Menghadapi Persalinan}

Pengukuran skor kecemasan ibu primigavida dalam menghadapi persalinan berdasarkan Hamilton Anxiety Rating Scale (HARS) pada kelompok intervensi dan kelompok kontrol (pre-test dan post-test) di Puskesmas Poka Rumah Tiga Kota Ambon menunjukkan perbedaan yang signifikan. Hasil uji paired t-test pada kelompok intervensi didapatkan $p=0,000$ yang artinya terdapat perbedaan yang signifikan pada kecemasan primigravida dalam menghadapi persalinan sebelum dan setelah diberikan penerapan kombinasi metode diskusi kelompok kecil dan pemodelan. Pada kelompok kontrol, hasil uji paired t-test didapatkan $p=0,394$ yang berarti tidak terdapat perbedaan kecemasan primigravida dalam menghadapi persalinan sebelum dan setelah diberikan modul persiapan menghadapi persalinan dan keterampilan merawat bayi pada kelompok kontrol (Tabel 2).

Tabel 2. Skor kecemasan primigravida (pre-test dan post-test) pada kelompok intervensi dan kelompok kontrol

\begin{tabular}{ccccccc}
\hline Kelompok Pengukuran & Mean & SD & $\begin{array}{c}\text { Min- } \\
\text { Max }\end{array}$ & Cl 95\% & $\begin{array}{c}\boldsymbol{p} \text { - } \\
\text { value }\end{array}$ \\
\hline Intervensi & Pre-test & 10,416 & 2,778 & $7-15$ & $8,651-12,182$ & 0,000 \\
& Post-test & 6,333 & 2,015 & $4-10$ & $5,053-7,613$ & \\
\multirow{2}{*}{ Kontrol } & Pre-test & 10,250 & 2,179 & $8-15$ & $8,865-11,634$ & 0,394 \\
& Post-test & 9,916 & 1,729 & $6-13$ & $8,817-11,015$ & \\
\hline
\end{tabular}

Keterangan: SD: Standar Deviasi; $\mathrm{Cl}$ : Confidence Interval

Hasil analisis statistik perbedaan skor kecemasan antara kelompok intervensi dengan kelompok kontrol berdasarkan nilai delta disajikan pada Tabel 3. Berdasarkan hasil uji independet t-test, kelompok intervensi mempunyai perbedaan kecemasan yang lebih besar dan signifikan bila dibandingkan kontrol.

Nilai delta kecemasan primigravida menghadapi persalinan antara pre-test dan post-test pada kelompok intervensi yang diberikan penerapan kombinasi metode diskusi kelompok kecil dan pemodelan adalah sebesar 4,083 (SD=2,466). Selisih skor tersebut menunjukan bahwa terdapat penurunan yang signifikan kecemasan primigravida dalam menghadapi persalinan pada responden setelah diberikan penerapan kombinasi metode diskusi kelompok kecil dan pemodelan.

Tabel 3. Uji beda skor kecemasan primigravida antara kelompok intervensi dengan kelompok kontrol berdasarkan nilai delta

\begin{tabular}{cccc}
\hline Kelompok & $\mathbf{N}$ & $\boldsymbol{\Delta}$ & $\boldsymbol{p}$-value \\
\hline Intervensi & 12 & $4,083 \pm 2,466$ & 0,000 \\
Kontrol & 12 & $0,333 \pm 1,302$ & \\
\hline
\end{tabular}

Keterangan: $\Delta$ : delta

\section{DISKUSI}

Hasil penelitian ini menunjukkan bahwa terdapat penurunan yang signifikan kecemasan primigravida dalam menghadapi persalinan setelah diberikan penerapan kombinasi metode diskusi kelompok kecil dan pemodelan. Hasil penelitian ini sejalan dengan penelitian yang dilakukan oleh Azadi et al, tahun 2016 yang menemukan bahwa terdapat pengaruh diskusi kelompok terhadap kecemasan primigravida dalam menghadapi persalinan (16). Selain itu, penelitian Devilata et al., juga menjelaskan bahwa pendidikan kesehatan sebelum persalinan (prenatal) pada primigravida dapat menurunkan kecemasan menghadapi persalinan. Kecemasan yang terjadi meliputi kecemasan menghadapi proses persalinan, keadaan umum, rasa sakit akan persalinan, biaya persalinan, komplikasi yang mungkin dihadapi, dukungan keluarga serta kecemasan akan bayinya. Oleh sebab itu ibu hamil membutuhkan informasi dan bimbingan yang memadai tentang persalinan selama kehamilannya(7).

Penelitian Swaroopa et al., mengemukakan bahwa pendidikan antenatal pada kelompok intervensi dapat mengurangi kecemasan primigravida dalam menghadapi persalinan dibandingkan dengan kelompok kontrol yang tidak diberikan pendidikan antenatal. Persalinan dianggap sebagai suatu proses yang alami dalam kehidupan wanita. Ibu yang pertama kali hamil atau primigravida akan mengalami rasa takut dan cemas. Rasa takut ini disebabkan karena kurangnya pengetahuan akan persalinan. Pendidikan antenatal yang diberikan selama kehamilan, akan memberikan pengetahuan dan wawasan tentang persalinan serta dapat mengajarkan cara mengatasi rasa sakit selama persalinan dan hal-hal yang harus dilakukan pada setiap tahap persalinan, sehingga kecemasan primigravida dalam menghadapi persalinan akan berkurang (17). Namun, hal ini tidak sejalan dengan penelitian yang dilakukan oleh Kim et al., tahun 2011 yang menemukan bahwa tidak ada perbedaan yang bermakna antara kecemasan ibu hamil dalam menghadapi persalinan pada kelompok intervensi yang diberikan pelatihan dasar program persalinan dibandingkan dengan kelompok kontrol(18). Banyak faktor penyebab yang dapat mempengaruhi terjadinya kecemasan dan saling berkesinambungan diantaranya: (1) ketidakpuasan selama kehamilan; (2) terkait dengan gangguan medis dan komplikasi yang mungkin dialami selama kehamilan baik dari ibu maupun kompikasi bagi bayi (19).

Sebagian besar primigravida merasa ragu akan kemampuannya sebagai seorang Ibu dan merasa cemas akan persalinannya nanti. Kehamilan dan persalinan merupakan suatu perubahan besar dalam hidupnya dan sebagian besar dari mereka tidak mengetahui peran dan perubahan apa saja yang terjadi dalam kehamilannya serta hal-hal yang harus dipersiapkan nanti ketika menjadi seorang Ibu (7). Menurut Entsieh et al., responden menginginkan informasi dini yang bersifat realistis tentang keterampilan menjadi orang tua dan membutuhkan dukungan serta bantuan dari tenaga kesehatan terutama pada masa awal sebelum persalinan(20).

Diskusi kelompok kecil merupakan sebuah diskusi dengan sesi waktu yang singkat untuk menghindari kebosanan pada peserta namun memiliki hasil yang sangat efektif (8). Keuntungan dari metode diskusi kelompok kecil dan pemodelan adalah merupakan suatu metode yang memungkinkan semua peserta berpartisipasi dan memunculkan sebuah gagasan atau pemikiran yang baru 
dari perserta sehingga dapat memecahkan suatu topik atau masalah yang dihadapi. Pemodelan atau peragaan secara langsung dapat meningkatkan kemampuan dan keterampilan ibu $(8,10)$. Pendidikan kesehatan dengan metode yang tepat dapat meningkatkan pengetahuan seseorang akan masalah yang dihadapi(21).

Kombinasi metode diskusi kelompok kecil dan pemodelan dalam penelitian ini terdiri dari komponen berupa tulisan, gambar dalam bentuk flip chart, leaflet serta alat peraga atau phantom yang diperagakan langsung dihadapan responden dalam bentuk diskusi kecil. Dengan adanya alat bantu media pembelajaran tersebut dan metode yang tepat seperti diskusi kelompok kecil dan pemodelan maka dapat memberikan stimulus kognitif yang baik bagi primigravida. Hal ini dapat meningkatkan pengetahuan primigravida tentang persalinan dan keterampilan ibu merawat bayinya. Pembahasan suatu masalah secara bersama-sama dalam suatu kelompok, dapat memungkinkan setiap peserta untuk mengungkapkan kecemasan mereka dalam menghadapi persalinan dengan teman kelompoknya yang memiliki perasaan yang sama. Hal ini dapat membatu mereka memahami permasalahan yang dihadapi selama proses kehamilan dan persalinan. Disamping itu, dengan adanya kegiatan memperagakan proses persalinan dan keterampilan merawat bayi dapat

\section{DAFTAR PUSTAKA}

1. Deklava L, Lubina K, Circenis K, Sudraba V, and Millere I. Causes of Anxiety during Pregnancy. Procedia-Social and Behavioral Sciences. 2015; 205(2015): 623-626.

2. Madhavanprabhakarana GK, D'Souza MS, and Nairy KS. Prevalence of Pregnancy Anxiety and Associated Factors. International Journal of Africa Nursing Sciences. 2015; 3(2015): 1-7.

3. Rico MAG, Rodrigus AJM, Diez SMU, and Real MCM. Analysis of the Relationship between Maternal Anxiety and Pregnancy. Progresos de Obstetricia y Ginecologia. 2010; 53(7): 273-279.

4. Mandagi DVV, Pali C, and Sinolungan JSV. Perbedaan Tingkat Kecemasan pada Primigravida dan Multigravida di RSIA Kasih Ibu Manado. Jurnal eBiomedik eBm. 2013; 1(1): 197-201.

5. Shodiqoh ER dan Syahrul F. Perbedaan Tingkat Kecemasan dalam Menghadapi Persalinan antara Primigravida dan Multigravida. Jurnal Berkala Epidemologi. 2014; 2(1): 141-150.

6. Marniyati L, Saleh I, and Soebyakto BB. Pelayanan Antenatal Berkualitas dalam Meningkatkan Deteksi Risiko Tinggi pada Ibu Hamil oleh Tenaga Kesehatan di Puskesmas Sako, Sosial, Sei Baung, dan Sei Selincah di Kota Palembang. Jurnal Kedokteran dan Kesehatan. 2016; 3(1): 355-362.

7. Devilata T and Swarna S. Effectiveness of Pre Delivery Preparation on Anxiety among Primigravida Mothers at Maternal Child Health Centre Tirupati, $A P$, India. IOSR Journal of Nursing and Health Science. 2015; 4(6): 19-24.

8. United Nations Children's Fund. Knowledge Exchange Toolbox: Group Methods for Sharing, Discovery and Co-creation. USA: Unicef Knowledge meningkatkan pengetahuan serta keterampilan ibu sehingga kecemasan ibu menghadapi persalinan dapat berkurang.

Menurut penelitian yang dilakukan oleh Shahhosseini et al, tahun 2015, kecemasan selama kehamilan memiliki efek yang sangat besar dan serius bagi kesehatan lbu maupun bayi. Efek kecemasan tersebut dapat berupa efek biologis, mental, perilaku serta efek medis. Oleh sebab itu diperlukan pelayanan prenatal yang terpadu bagi ibu hamil yang mengalami kecemasan (22). Penelitian ini membuktikan bahwa penerapan kombinasi metode diskusi kelompok kecil dan pemodelan dapat lebih menurunkan kecemasan primigravida dalam menghadapi persalinan, bila dibandingkan hanya pemberian modul.

\section{UCAPAN TERIMAKASIH}

Peneliti mengucapkan terima kasih kepada Pemerintah Kota Ambon, Dinas Kesehatan Kota Ambon, dan Puskesmas Poka Rumah Tiga Kota Ambon yang telah mengizinkan peneliti dalam melakukan penelitian. Fakultas Kedokteran Universitas Pattimura Kota Ambon telah mengeluarkan rekomendasi persetujuan etik penelitian ini dengan Nomor: 190/FKKOM.ETIK/VIII/2017.

\section{Exchange; 2015.}

9. Nuardi, Syafii MS, and Anuar IH. The Effect of Using Buzz Group Technique on Students Ability in Writing Analytical Exposition Paragraph. Indonesian Journal of Intergarated of English Language Teaching. 2016; 2(2): 209-220.

10. Saleh A. Pendekatan Modelling Keperawatan Anak terhadap Pengetahuan, Kemampuan Praktik dan Percaya Diri Ibu dalam Menstimulasi Tumbuh Kembang Bayi 0-6 Bulan. Jurnal Ners. 2011; 6(2): 175-186.

11. Ikromah JN, Asmaningrum N, and Sulistiyorini L. Perbedaan Metode Buzz Group Discussion dengan Ceramah Audiovisual terhadap Tingkat Pendidikan Warga Binaan tentang HIV/AIDS di Lembaga Pemasyarakatan Klas IIA Kabupaten Jember. eJournal Pustaka Kesehatan. 2015; 3(1): 82-88.

12. Majid A. Strategi Pembelajaran. Bandung: PT. Remaja Rosdakarya; 2014.

13. Sugiyono. Metode Penelitian Kuantitatif, Kualitatif, dan R\&D. Bandung: Alfabeta; 2014.

14. Sastroasmoro S. Dasar-dasar Metodologi Penelitian Klinis. Edisi Keempat. Jakarta: Sagung Seto; 2011.

15. Hasnah $\mathrm{H}$, Amiruddin $\mathrm{R}$, Sirajuddin $\mathrm{S}$, and Mappaware NA. Effectiveness of Comprehensive Midwifery Care on Anxiety Level of Pregnant Mother in Facing Labor Period. Internasional Journal of Sciences Basic and Applied Research. 2017; 35(2): 22-30.

16. Azadi ES, Jalali A, Bakhteh A, Rezaei $M$, and Ashtareian H. The Effect of Group Discussion on Anxiety of Primigravidas. Research Journal of Medical Sciences. 2016; 10(5): 498-502.

17. Swaroopa HN and Deepthi G. Effect of Antenatal 
Education in Improving Maternal Confidence and Reducing Anxiety about Labor in Primigravida Women Attending Saveetha Medical College and Hospital, Chennai, Tamil Nadu, India. Internasional Journal of Pharma and Bio Sciences. 2017; 8(1): 261-265.

18. Kim S, Kim HS, and Cheong HY. Effects of a Coachingbased Childbirth Program on Anxiety and Childbirth Self-efficacy among Primigravida Women. Korean Journal of Women Health Nursing. 2011; 17(4): 369377.

19. Hassan HE, Said SAE, and Hassanine ST. Disparities of Prevalence and Causes of Maternal Antenatal Anxiety among Primigravida Pregnant Women in
Egypt. American Research Journal of Nursing. 2017; 3(1): 1-15.

20. Entsieh $\mathrm{AA}$ and Hallström IK. First-time Parents' Prenatal Needs for Early Parenthood Preparation-A Systematic Review and Meta-Synthesis of Qualitative Literature. Midwifery. 2016; 39(2016): 1-11.

21. Amelia CR. Pendidikan Sebaya Meningkatkan Pengetahuan Sindrom Pramenstruasi pada Remaja. Jurnal Kedokteran Brawijaya. 2014; 28(2): 152-154.

22. Shahhosseini Z, Pourasghar M, Khalilian A, Salehi F. $A$ Review of the Effects of Anxiety During Pregnancy on Children's Health. Materia Socio Medica. 2015; 27(3): 200-202. 